\title{
VERBAL CONTENTS EXPRESSED BY MOTHERS OF PRETERM INFANTS WITH CLINICAL EMOTIONAL SYMPTOMS
}

\author{
Luciana Leonetti Correia ${ }^{1}$ \\ Ana Emília Vita Carvalho ${ }^{2}$ \\ Maria Beatriz Martins Linhares ${ }^{3}$
}

Correia LL, Carvalho AEV, Linhares MBM. Verbal contents expressed by mothers of preterm infants with clinical emotional symptoms. Rev Latino-am Enfermagem 2008 janeiro-fevereiro; 16(1):64-70.

The aim of the present study was to characterize verbal contents expressed by preterm neonates' mothers during psychological support intervention. The sample was composed by 20 mothers of pre-term and very low birthweight neonates, hospitalized in NICU, allocated into two groups: 10 mothers with emotional clinical symptoms (MECS) and 10 mothers with no symptoms (MNECS), assessed by the Beck Depression Inventory and the State-Trait Anxiety Inventory. The verbal behavior expressed by mothers in the psychological support group was recorded, transcribed and categorized. The results show that three verbal categories were more frequent: negative feelings or reactions, followed by positive feelings or reactions and communication with the health staff. The comparison between groups reveals that MECS presented more expressions in the first category in comparison to MNECS. The identification of the feelings and reactions of pre-term neonates' mothers and emotional clinical symptoms should be included for appropriate intervention in developmental care in NICU.

DESCRIPTORS: verbal behavior; infant premature; anxiety; depression; intensive care units

\section{CONTENIDO VERBAL EXPRESADO POR LAS MADRES DE BEBÉS PREMATUROS CON SÍNTOMAS EMOCIONALES CLÍNICOS}

El objetivo de este estudio fue caracterizar los contenidos verbales maternos expresados durante una intervención de apoyo psicológico. La muestra estaba compuesta por 20 madres de recién nacidos prematuramente, con un peso abajo de lo normal, internados en una UTI Neonatal; la muestra estaba constituida por 10 madres con indicadores clínicos emocionales (MCIE) y 10 madres sin estos indicadores (MSIE); las expresiones fueron evaluadas por medio de los Inventarios de Depresión de Beck y de Ansiedad Trazo/Estado. Las expresiones verbalizadas por las madres en el grupo de apoyo fueron gravadas, transcritas y clasificadas en categorías. Los resultados mostraron que las categorías sobre los sentimientos o reacciones maternas con connotación negativa o connotación positiva y la comunicación con el equipo de salud fueron las más frecuentes. Comparando los grupos, el Grupo MCIE verbalizó más expresiones referentes a la primera categoría que el Grupo MSIE. La identificación de los sentimientos y reacciones de las madres de neonatos prematuros y de los síntomas emocionales clínicos deben ser incluidas para realizar una adecuada intervención en el desarrollo individualizado del bebé en una UTIN.

DESCRIPTORES: conducta verbal; prematuro; ansiedad; depresión; unidades de terapia intensiva

\section{CONTEÚDOS VERBAIS EXPRESSOS POR MÃES DE BEBÊS PREMATUROS COM SINTOMAS EMOCIONAIS CLÍNICOS}

O objetivo do estudo foi caracterizar os conteúdos verbais maternos expressos durante intervenção de apoio psicológico. A amostra foi composta por 20 mães de neonatos pré-termo com muito baixo peso, internados em UTI Neonatal, distribuída em 10 mães com indicadores clínicos emocionais (MCIE) e 10 mães sem estes indicadores (MSIE), avaliadas pelos Inventários de Depressão de Beck e de Ansiedade TraçoEstado. As verbalizações maternas expressas no grupo de apoio foram gravadas, transcritas e categorizadas. Os resultados mostraram que as categorias sobre sentimentos ou reações maternas com conotação negativa ou conotação positiva e comunicação com a equipe de saúde foram as mais freqüentes. Na comparação entre os grupos, o Grupo MCIE verbalizou mais expressões referentes à primeira categoria quando comparado ao Grupo MSIE. A identificação dos sentimentos e reações de mães de neonatos pré-termo e dos sintomas emocionais clínicos deve ser incluída para adequada intervenção em cuidado desenvolvimental em UTIN.

${ }^{1}$ M.Sc. in Mental Health, Doctoral Student, e-mail: luleonetti@hotmail.com; ${ }^{2}$ Ph.D. in Science: Psychology, Psychologist at the Foundation for Support to Teaching Research and Care at the Hospital das Clinicas; ${ }^{3}$ Ph.D., Professor, e- mail: linhares@fmrp.usp.br. University of São Paulo at Ribeirão Preto Medical School, Brazil 


\section{INTRODUCTION}

The birth of a pre-term infant with extremely low weight represents a "psychological crisis" in the family. Especially for the mother, this is an unpredictable situation, which causes stress and feelings of impotence and increases the incidence of anxiety and depression symptoms ${ }^{(1-3)}$. Studies assessing maternal anxiety and depression showed that these symptoms occur simultaneously, which represent potential risk factors for the infant's development and the mother-infant relationship ${ }^{(2-3)}$.

In order to minimize the impact of immediate and adverse consequences for the relation between the mother and the preterm infant hospitalized at the Neonatal Intensive Care Unit (NICU) some changes in neonatal care practice are proposed ${ }^{(3-4)}$. The "Individualized Developmental Care Approach Centered on families of extremely low-weight preterm infants" has marked a new age in interdisciplinary work at NICUs ${ }^{(4-5)}$.

The psychological support group may represent a setting to facilitate feelings and guide reflections, in which support and protection are offered to the mother so that she can develop better conditions to face the infant's hospitalization period at the $\mathrm{NICU}^{(6)}$. Studies were carried out to assess the topics of the contents of maternal verbalizations while participating in psychological support groups for mothers of infants hospitalized at NICUs ${ }^{(7)}$. However, in this respect, the analysis of the content of infants' mothers verbalizations has not considered mental health aspects.

This study aimed to characterize the verbal contents of preterm infants' mothers, expressed during a psychological intervention context, comparing two groups of mothers who are different with respect to clinical emotional indicators.

\section{METHOD}

Participants

The sample consisted of 20 mothers of preterm infants, with birth weight equal to or lower than 1,500 grams, who participated in the "Psychological Support Program for mothers of preterm infants hospitalized at the Neonatal Intensive Care Unit" from June 2001 to February 2003, promoted by the Psychological Pediatrics Service of the University of São Paulo at Ribeirão Preto Medical School Hospital das Clínicas (HCFMRP- USP), along with the Neonatology Service. From an initial sample of twenty-seven mothers, seven were excluded; one due to the baby's death and six due to psychiatric disorders (before and after the infant's birth). The study was approved by the Neonatology and Obstetrics and Gynecology Departments and by the Research Ethics Committee at the HCFMRP- USP.

Instruments and materials

The following instruments and materials were used for selecting the participants and for data collection: a) SCID Non - Patient - Structured Clinical Interview for DSM - III - $\mathrm{R}^{(8)}$; b) State-Trait Anxiety Inventory -STAI with translation and Brazilian adaptation $^{(9)}$. In the state-anxiety subscale, the mothers had to answer items about their infant's birth. The STAI scores were transformed into percentiles and the percentile $\geq 75$ was adopted as the cut-off percentile for discriminating state-trait anxiety clinical indicators of anxiety; c) Beck's Depression Inventory (BDI) with translation and Brazilian adaptation ${ }^{(10)}$. The cut-off score used to identify the clinical depression indicators was the score above $20^{(11)}$; d) "Precious Reminders for Mommy -Booklet for psychological support of preterm infants' mothers"(12); e) Medical chart of infants from HCFMRP- USP; f) Interview guide for socio-demographic data collection of mothers and infants ${ }^{(13)}$; g) Recorder, cassette tape and batteries.

\section{PROCEDURE}

Data collection

Participant selection: The psychologist (second author) individually applied the Structured Clinical Interview for DSM - III - R / SCID Non Patient, without diagnostic purposes, in order to exclude mothers who presented psychiatric history After confirming the inclusion criteria, the "Free and Informed Consent Term" was signed.

Group formation, according to clinical emotion symptoms: the psychological assessment was performed in order to identify two groups of mothers, different in terms of clinical emotion indicators, which are: ten mothers with emotional indicators (M-E) and 
ten mothers without emotional indicators (M-NE). For the formation of both groups of mothers, the first author used the Trait-State Anxiety Inventory- STAI and Beck's Depression Inventory - BDI. The clinical level mentioned in instruments and materials was adopted.

Data collection: the data were obtained during psychological intervention sessions with mothers of premature babies, which aimed to offer psychological support and guide the mothers during babies' hospitalization at the NICU. This procedure is performed weekly at the NICU, weekly, with the support of a psychologist (second author). The data that will be assessed in the present study consist of maternal verbal reports obtained during 16 psychological group intervention sessions, in which the "Precious Reminders for Mommy -Booklet for psychological support of preterm infants' mothers" was used ${ }^{(12)}$. The booklet is organized in chapters that present the course of events that frequently involve parents of preterm hospitalized babies, which are: The impact of preterm birth; Visiting at NICU; How can I have contact with my baby?; News on the baby hospitalized at NICU; How to breastfeed my baby hospitalized at NICU; Discharge. Each chapter is introduced by extracts of mothers' brief reports regarding the topics addressed in the chapters. The procedure regarding the use of "Precious Reminders for Mommy" is described in Carvalho ${ }^{(13)}$. After the participant mothers' previous agreement, these sessions were audio-recorded for later literal transcription by a second psychologist (first author), who was "blind" regarding the characteristics and the results of the mothers' psychological assessments. The sessions lasted approximately 60 minutes. Thus, in total, 960 minutes of recording were used for assessment.

Informations about the infant's health history: information was collected through documentary analysis of medical records, with a view to identifying the following variables of the infant's neonatal risk: birth weight (grams), gestational age (weeks) and hospitalization time at NICU (days).

Data analysis

Preparing data analysis: the audio recordings were literally transcribed for later assessment of the maternal verbalization topic content. These transcriptions were performed by the second author and were later submitted to the psychologist in charge of carrying out the sessions (first author), so that possible transcription flaws were corrected.

Elaborating the system of categories for assessing the verbal content: the content of the transcribed verbalizations was assessed through a quantitative and interpretative system ${ }^{(14)}$. The elaboration of this system of categories for assessing verbal content is described in Correia(15). The feasibility index between two independent coders of the category system of the mothers's verbal content was established. The coders were expertise in systematic observation of human behavior. The feasibility index obtained between two coders was $85 \%$. Then, the category system and subcategories for assessing the mothers' verbal content was adjusted to clarify disagreements between assessors and applied to all data of the study sample. The system categories and subcategories of the mother's verbal content assessment are presented next.

I - Feelings / mother's reactions with positive meaning: love or pride for the baby; happiness to see, visit and take care of the baby; wish for the baby's survival; adaptation, acceptance, overcoming, hope or tranquility facing the baby's premature condition; need or wish to establish contact, approach or touch the baby; wish for breastfeeding, wish for discharge and taking care of the baby after that; attention to the baby; II - Feelings / mother's reactions with negative meaning: II.1 - Negative reactions: Fear of approaching, of harming or establishing contact with the baby; discomfort, anxiety, apprehension, nervousness, scarsity or insecurity; alarm, shock, surprise, panic, fearfulness or grief; cry or sadness; rejection, insurrection, denial or detachment from her preterm baby; impatience or restlessness; II.2 - Doubts and comments on the birth condition and health state of the preterm baby; III- Feelings/ mother's reactions with oscillation or ambivalent meaning; IV Mother's feelings of guilt: Guilt given by another; free of guilt; self-attribution of guilt; $\mathbf{v}$ - Mother's expectations regarding baby's birth condition and health team: V.1 - Expectations regarding baby's birth condition: Expectations regarding baby's health state; relative expectation regarding "normal" weight; relative expectation regarding "normal" size; relative expectation regarding full-term birth; relative expectation regarding baby's gender. V.2 Expectations regarding health team; VI - Mother's 
perceptions regarding development, evolution and baby's health: Positive or Negative; VII Mother's conceptions about prematurity: Unable to perform mother role; mother's indifference; mother's dependence regarding the infant; infant's dependence regarding the mother; VIII Comparisons with other babies and mothers: Positive or Negative; IX - Communication and mother's relationship with health team: Omitted communication; provided communication; active search for information; fear or shame of asking about the baby; help or care from the health team; team's prohibition to see or visit the baby; opposition or insecurity regarding health team; X - Mentioning religious faith; XI - Descriptions of motherbaby relationship; XII- Identification with material used in intervention program: Identification or non identification; XIII - Friends and relatives' incentive and support; XIV Comparisons with the father; XV - Comparison with other siblings.

Data analysis: first, a descriptive statistical analysis was performed, with the use of frequency, percentage, proportion and median, according to the data. Quantitative descriptive analysis of topic verbal categories was performed in terms of frequency and percentage of mother's verbal contents. The frequency of each category or subcategory corresponded to the number of times they were expressed by the mothers. The percentage of each category was calculated by dividing the total frequency of mother's verbalizations by the total frequency of mother's verbalizations expressed in the set of intervention sessions. The percentage of each subcategory was calculated by dividing the frequency of verbalizations of the subcategory by the total frequency of verbalizations of the corresponding category. Later, the mothers were identified regarding emotional clinical indicators and the mother's verbal contents found in M-E and MNE were assessed, respectively. The comparison between groups ( $M-E$ vs $M-N E$ ) aimed to characterize and identify possible differences between the groups regarding the feelings, thoughts and the mother's verbally expressed reactions. The continuous variables were treated with Mann Whitney's non parametric test and, for the discrete variables, the Chi-square test or Fisher's exact test was used. The relations among the infant's neonatal variables were assessed (birth weight, clinical risk index for babies - CRIB - and baby's NICU hospitalization period). In both groups,
Spearman's correlation was used. For statistical data treatment, the Statistical Package for Social Sciences (SPSS) for Windows version 12.0 was used. The significance level adopted for this study was 5\%.

\section{RESULTS}

Table 1 - Demographic characteristics of mothers and infants from $M-E$ and $M-N E$ groups

\begin{tabular}{|c|c|c|c|}
\hline Sample characteristics & $\begin{array}{c}M-E \\
(n=10)\end{array}$ & $\begin{array}{l}\text { M-NE } \\
(n=10)\end{array}$ & $\begin{array}{c}p \\
\text { value }\end{array}$ \\
\hline Mother age (years) - Median (Min-Max) & $26(19-39)$ & $24(14-39)$ & 0.35 \\
\hline \multicolumn{4}{|l|}{ Mother school grade (proportion) } \\
\hline 1st Grade & 0.80 & 0.50 & 0.30 \\
\hline 2nd Grade & 0.20 & 0.40 & \\
\hline 3rd Grade & 0 & 0.10 & \\
\hline Number of children - Median (Min-Max) & $2(1-5)$ & $1(1-3)$ & 0.14 \\
\hline \multicolumn{4}{|l|}{ Mother professional occupation (proportion) } \\
\hline Housewife & 0.70 & 0.40 & \\
\hline Worker & 0.30 & 0.30 & 0.14 \\
\hline Student & 0 & 0.30 & \\
\hline \multicolumn{4}{|l|}{ Civil union (proportion) } \\
\hline Stable union & 1.00 & 0.70 & 0.10 \\
\hline Single & 0 & 0.30 & \\
\hline Gestational age (weeks) - Median (Min- Max) & $28(23-35)$ & $28(23-32)$ & 0.97 \\
\hline Birth weight (grams) - Median (Min- Max) & $945(710-1,485)$ & $1.125(845-1,495)$ & 0.19 \\
\hline \multicolumn{4}{|l|}{ Gender (proportion) } \\
\hline Male & 0.60 & 0.50 & 0.50 \\
\hline Female & 0.40 & 0.50 & \\
\hline Apgar -5th minute (score) - Median (Min- Max) & $8(7-10)$ & $9(5-10)$ & 0.79 \\
\hline $\begin{array}{l}\text { Neonatal Clinical Risk Index / CRIB (score) - } \\
\text { Median (Min- Max) }\end{array}$ & $3(0-10)$ & $2(0-10)$ & 0.34 \\
\hline \multicolumn{4}{|l|}{ Appropriate for gestational age (proportion) } \\
\hline SGA & 0.70 & 0.67 & 0.63 \\
\hline AGA & 0.30 & 0.33 & \\
\hline NICU hospitalization period (days) - Median (Min- Max) & $38(3-65)$ & $17(4-92)$ & 0.35 \\
\hline Hospitalization period (days) - Median (Min- Max) & $69(26-146)$ & $49(25-129)$ & 0.35 \\
\hline
\end{tabular}

M-E: Mothers with emotional indicators of anxiety and/or depression; M$\mathrm{NE}$ : Mothers without emotional indicators of anxiety and/or depression. SGA: small for gestational age; AGA: adequate for gestational age.

Table 1 shows that there were no differences between groups regarding the mother's and infants' neonatal characteristics. Focusing on maternal variables, in both groups, most mothers were young, had few kids, lived in a stable civil union, had finished elementary school and did not work. In both groups, infants had a median gestational age of 28 weeks and the median birth weight value was around 1,000 grams. Both groups presented a high median score on the Apgar index and the neonatal index, measured by CRIB, was equal to or three points lower than the median, indicating moderate clinical neonatal status for the infants. The Apgar and CRIB scores presented a wide range, suggesting infants' individual variation regarding these aspects. Most of the infants in both groups are classified as "small for gestational age", i.e., had birth weight lower than expected for 
gestational age. The NICU period and the infant's total period presented similar median values, with a wide range in both groups.

Complementing data from Table 1 , in both groups, a significant positive correlation was observed between the infant's NICU hospitalization period and the CRIB index; the higher the neonatal clinical risk, the longer the NICU period $(r=0.74[p \leq 0.02] ; r=0.87$ $[p \leq 0.002]$, respectively. Otherwise, a significant negative correlation between NICU hospitalization period and birth weight was found; the lower the birth weight, the longer the hospitalization period $(r=-0.72$ $[p \leq 0.01] ; r=-0.69[p \leq 0.02]$, respectively).

Table 2 - Mother's verbal content categories and subcategories - M-E and M-NE groups- in terms of frequency (f) and percentage (\%)

\begin{tabular}{|c|c|c|c|c|}
\hline \multirow{2}{*}{$\begin{array}{l}\text { Mother's verbal content } \\
\text { Categories and subcategories }\end{array}$} & \multicolumn{2}{|c|}{$M-E(n=10)$} & \multicolumn{2}{|c|}{ M-NE $(n=10)$} \\
\hline & $\mathrm{f}$ & $\%$ & f & $\%$ \\
\hline Feelings/mother's reactions with negative meaning & 122 & 36 & 107 & 32 \\
\hline Doubts or comments & 47 & 38 & 49 & 46 \\
\hline Negative reactions & 75 & 62 & 58 & 54 \\
\hline Addressing fear, harming or establishing contact with the baby & 39 & 52 & 31 & 54 \\
\hline Rejection, insurgence, denial or separation from the baby & 11 & 14 & 2 & 3 \\
\hline $\begin{array}{l}\text { Discomfort, anxiety, apprehension, nervousness, scarsity or } \\
\text { insecurity }\end{array}$ & 9 & 12 & 11 & 19 \\
\hline Cry or sadness & 9 & 12 & 4 & 7 \\
\hline Terror, shock, surprise, panic, feartulness or grief & 6 & 8 & 9 & 15 \\
\hline Impatience or restlessness & 1 & 2 & 1 & 2 \\
\hline Feelings/mother's reactions with positive meaning & 63 & 19 & 79 & 24 \\
\hline $\begin{array}{l}\text { Adaptation, acceptance, overcoming, hope or tranquility facing } \\
\text { the baby's prematurity }\end{array}$ & 24 & 38 & 39 & 50 \\
\hline Wish for discharge and taking care of the baby after that & 13 & 20 & 7 & 9 \\
\hline $\begin{array}{l}\text { Need or wish for establishing contact, approaching or touching } \\
\text { the baby }\end{array}$ & 10 & 17 & 17 & 22 \\
\hline Happiness to see, visit and take care of the baby & 5 & 8 & 5 & 6 \\
\hline Wish for breastfeeding & 5 & 8 & 5 & 6 \\
\hline Wish for the baby's survival & 3 & 5 & 3 & 4 \\
\hline Love or pride for the baby & 2 & 3 & 1 & 1 \\
\hline Attention to the baby & 1 & 1 & 2 & 2 \\
\hline Communication and relationship with health team & 38 & 12 & 52 & 17 \\
\hline Provided communication & 15 & 40 & 12 & 24 \\
\hline Mother active search for information & 14 & 37 & 16 & 30 \\
\hline Help or care from the health team & 4 & 10 & 6 & 12 \\
\hline Fear or shame of asking for information about the baby & 2 & 6 & 5 & 10 \\
\hline Omitted communication & 1 & 3 & 5 & 10 \\
\hline Team prohibition regarding seeing or visiting the baby & 1 & 3 & 4 & 7 \\
\hline Mother opposition or insecurity regarding health team & 1 & 3 & 4 & 7 \\
\hline $\begin{array}{l}\text { Mother's perceptions regarding development, evolution and } \\
\text { baby's health }\end{array}$ & 30 & 9 & 28 & 10 \\
\hline Negative & 17 & 56 & 16 & 57 \\
\hline Positive & 13 & 44 & 12 & 43 \\
\hline Descriptions of mother-baby relationship & 20 & 6 & 8 & 2,5 \\
\hline Other categories (with percentage $<5 \%$ ) & 60 & 18 & 46 & 14,5 \\
\hline Total & 333 & 100 & 320 & 100 \\
\hline
\end{tabular}

Table 2 shows that the three most frequent categories in both groups, from the most to the least frequent, were: Feelings or mother reactions with negative meaning, Feelings or mother reactions with positive meaning and Communication and mother's relationship with health team. Regarding the mother's verbalizations about Feelings or mother's reactions with negative meaning, it is observed that the Negative Reactions subcategory was more verbalized than Doubts and Comments, in both groups. Focusing on Negative Reactions, the verbalizations about fear of approaching, of harming or of establishing contact with the baby were the most distinguished in both groups. The M-E Group verbalized more about rejection, insurrection, denial or baby's separation than the M-NE Group. Regarding maternal verbalizations about Feelings/ mother's reactions with positive connotations, it is observed that mothers from $M-E$ showed a higher tendency of verbalizing less than M-NE mothers about adaptation, acceptance, overcoming, hope or tranquility facing the baby's premature condition and the need or maternal wish for establishing contact, approaching or touching the baby. However, M-E mothers expressed more the wish of discharge and taking care of the baby after that when compared to M-NE mothers. It is observed that, in the category of Communication and the mother's relationship with health team category, mothers from the M-E group verbalized more than M-NE about expressions related to the mother's active search for information about the infant.

\section{DISCUSSION}

In the present study, the mother's of preterm infants hospitalized in NICU reported predominantly about feelings or reactions with negative meaning, independently of the presence of clinical symptoms of anxiety or depression. Otherwise, the mothers with emotional clinical indicators showed a tendency of expressing feelings or mother's reactions with negative meaning when compared to mothers that did not present such indicators; the mother presented a tendency of verbalizing more on expressions of feeling or reactions with positive meaning and about the communication and relationship with the health team, when compared to M-E mothers. Possibly, the presence of the mother's clinical emotional indicators of anxiety and depression may have stimulated a greater occurrence of verbalizations about feelings and reactions with negative meaning. These verbalizations, however, are expected due to the impact the preterm birth and early NICU infant hospitalization represent for mothers within this context ${ }^{(3)}$. 
Although it seems to be paradoxical those mothers of both groups have verbalized about feelings and negative and positive feelings and reactions, these data suggest that mothers of premature infants may experience ambiguous feelings. The behavior of persons in a psychological crisis comprehends oscillations and ambivalences of feelings and reactions, triggered by unexpected situations, like preterm birth and the infants' early hospitalization at the $\mathrm{NICU}^{(1)}$. In order to restructure the mother's emotional equilibrium and minimize the unfavorable consequences of the presence of the mother's emotional indicators, it is relevant to supply psychological support to mothers, in the neonatal period. Support and protection are offered to the mother, so that she can develop better conditions to cope with the infant's NICU hospitalization ${ }^{(5)}$. Then, it can contribute to a significant reduction of the mother's clinical symptoms of anxiety and depression $^{(2)}$.

The mother's verbal reports suggest that preterm birth and early NICU infant's hospitalization are variables that may compromise mother and family emotional equilibrium, corroborating with previous studies $^{(3 ; 5)}$; however, negative mother verbalizations related to birth and infant's hospitalization showed a tendency of occurring more in mothers with emotional clinical symptoms of anxiety or depression than in mothers who did not present them.

\section{REFERENCES}

1. Maldonado MT. Psicologia da gravidez: parto e puerpério. 14a ed. São Paulo (SP): Saraiva; 1997.

2. Preyde M, Ardal F. Effectiveness of a parent "buddy" program for mothers of very preterm infants in a neonatal intensive care unit. CMAJ 2003; 168(8):969- 73.

3. Linhares MBM, Carvalho AEV, Correia LL, Gaspardo CM, Padovani FHP. Psicologia pediátrica em neonatologia de alto risco: promoção precoce do desenvolvimento de bebês prematuros. In: Crepaldi MA, Linhares MBM, Perosa GB, organizadoras. Temas em Psicologia Pediátrica. São Paulo (SP): Casa do Psicólogo; 2006. p. 109- 46.

4. Als H. Towards a synactive theory of development: promise for the assessment of infant individuality. Infant Ment Health J $1982 ; 3: 229-43$.

5. Buarque V, Lima MC, Scott RP, Vasconcelos MG. The influence of support groups on the family of risk newborns and on neonatal unit workers. J Pediatr 2006; 82:295-301.

6. Scochi CGS, Kokuday MLP, Riul MJS, Rossanez LSS, Fonseca LMM, Leite AM. Incentivando o vínculo mãe-filho em situação de prematuridade: as intervenções de enfrentamento no Hospital das Clínicas de Ribeirão Preto. Rev Latino-am Enfermagem 2003 julho-agosto; 11(4):539-43.
The present study offers the advantage of being accomplished in an applied natural setting, which grants "ecological validity" to the obtained results, i.e., the analysis of the verbalized mother's reports preceded a context of immediate experience to the premature infant birth and his/her hospitalization at NICU. However, its results are representative of a small sample selected at a university hospital, which demands care when generalizing the findings to other mother samples.

Finally, the advance in maternal verbalization analysis about the infants' prematurity may improve the understanding of the mother's psychological universe, who are the primary and long-term caregivers of these vulnerable infants.

\section{FINAL COMMENTS}

The investigation about mothers' emotional indicators is relevant for clinical practice. During hospitalization, the clinical care focus is the premature infant and his/her clinical evolution. Yet, as actions that depend on the mother to promote well being and infant's health are introduced, such as breastfeeding, visits, skinto-skin contact and Kangaroo Care Method, the knowledge of thoughts, feelings and maternal beliefs helps to guide adequate implementation of intervention strategies that facilitate developmental and individualized care of the infant.
7. Aylward GP. Methodological issues in outcomes studies of at-risk infants. J Pediatr Psychol 2002; 27(10):37-45.

8. Spitzer RL, Williams JB, Gibbon M, First MB. Instruction manual for the structured clinical interview for DSM III - $\mathrm{R}$ (SCID, 5/11/89 Revision). New York: Biometrics Research Department. New York State Psychiatric Institute; 1989.

9. Biaggio AMB, Natalício L, Spielberger CD. Desenvolvimento da forma experimental em português do Inventário de Ansiedade Traço-Estado (IDATE) de Spielberger. Arquiv Bras Psicol Aplicada 1979; 29(3):3144.

10. Cunha JA. Manual da versão em português das Escalas Beck. São Paulo: Casa do Psicólogo; 2001.

11. Kendall PC, Smith TW, Donnell C, Ronank K. Cognitive specificity in emotional distress. J Pers Soc Psychol 1987; 53(4):734-42.

12. Carvalho AEV, Linhares MBM. Lembretes preciosos para a mamãe- Livro de apoio à orientação psicológica de mães de recém-nascidos pré-termo [manual]. In: Carvalho AEV. Indicadores emocionais maternos e intervenção psicológica durante hospitalização do bebê pré-termo em UTI Neonatal. [tese]. Ribeirão Preto (SP): Faculdade de Filosofia, Ciências e Letras de Ribeirão Preto/ USP; 2005. 
13. Carvalho AEV. Indicadores emocionais maternos e intervenção psicológica durante hospitalização do bebê prétermo em UTI Neonatal. [tese]. Ribeirão Preto (SP): Faculdade de Filosofia, Ciências e Letras de Ribeirão Preto/USP; 2005.

14. Biasoli-Alves ZMM A pesquisa em psicologia- análise de métodos e estratégias na construção de um conhecimento que se pretende científico. In: Romanelli G, Biasoli-Alves ZMM, organizadores. Diálogos metodógicos sobre prática de pesquisa. Ribeirão Preto (SP): Legis Summa; 1998. p. 135-57.

15. Correia LL. Conteúdos verbais de mães de bebês prétermo internados em UTI Neonatal, diferenciadas quanto a indicadores clínicos emocionais de ansiedade e depressão. [Dissertação]. Ribeirão Preto (SP): Faculdade de Medicina/ USP; 2005. 